\title{
XBRL Adoption, Information Asymmetry, Cost of Capital, and Reporting Lags
}

\author{
Chae-Won Ra*, Ho-Young Lee \\ School of Business, Yonsei University, Seoul, Korea \\ Email: "hylee@yonsei.ac.kr
}

How to cite this paper: Ra, C.-W. and Lee, H.-Y. (2018) XBRL Adoption, Information Asymmetry, Cost of Capital, and Reporting Lags. iBusiness, 10, 93-118.

https://doi.org/10.4236/ib.2018.103006

Received: May 7, 2018

Accepted: August 10, 2018

Published: August 13, 2018

Copyright (C) 2018 by authors and Scientific Research Publishing Inc. This work is licensed under the Creative Commons Attribution International License (CC BY 4.0).

http://creativecommons.org/licenses/by/4.0/

\begin{abstract}
The voluntary and mandatory introduction of a new information technology, XBRL, in 2006 and 2007 by the Financial Supervisory Services of Korea has significantly affected capital markets, possibly through a reduction in the information asymmetry between firms and users of financial information. This study examines how changes in the information environment attributable to XBRL adoption affect the cost of capital and whether the adoption reduces reporting lags for both voluntary and mandatory filers. Using a 152 firm-year sample, this study finds evidence that the cost of equity capital declined after XBRL adoption, and this decline was greater for voluntary filers with higher information asymmetry. Mandatory filers also experienced incremental reductions in their costs of equity capital after the adoption. Additionally, this study finds evidence that financial reporting lags decrease for both voluntary and mandatory adopters after the adoption. Firms with reduced reporting lags after the adoption experience reduction in cost of capital.
\end{abstract}

\section{Keywords}

Information Technology, XBRL, Cost of Equity Capital, Information Asymmetry, Reporting Lag

\section{Introduction}

Technological development reduces information asymmetry among capital market participants, and thus is expected to reduce the cost of capital. The timeliness and comparability of financial information are key elements that affect information asymmetry between providers and users of the information in capital markets. Although the adoption of eXtensible Business Reporting Language (hereafter XBRL) as a capital market disclosure mechanism significantly affected the 
timeliness and comparability of financial information, few studies examine the effects of a technological environment change on the cost of capital.

With the rapid development of Internet and information technology (IT), the environment for financial disclosure has also changed. Given this technology advancement, information users can now gain real-time access to information through various channels. In particular, information users are moving from the news media and paper-based disclosure system to Internet-based electronic disclosure system, enabling corporate disclosures to be updated and available to interested parties in real time. In addition, the electronic disclosure system has led to another groundbreaking improvement in the information environment of capital markets, which is the introduction of the XBRL-based disclosure system. The XBRL system is particularly useful for accounting information under internationally standardized taxonomies, allowing information users to easily search for and facilitate the detection and collection of information. Through the XBRL taxonomy, the accounting information became standardized, and therefore easily comparable across firms in capital markets. Therefore, the XBRL taxonomy provides more timely and relevant accounting information for decision makers.

In 2006, the Financial Supervisory Service of Korea (FSS, the Korean equivalent of the US Securities and Exchange Commission) introduced K-GAAP-based XBRL in the financial disclosures for listed firms on a voluntary basis. In 2007, FSS mandated XBRL filings for listed firms. In 2011, under the Act on Independent Audits of Corporations, the FSS mandated all firms, regardless of their listing status, disclose their annual reports, including their financial statements, using XBRL. Korea has been considered as an excellent example of prompt adoption and establishment of XBRL in the realm of globalization, thereby witnessing an improvement in both the information environment and accounting transparency. Therefore, an analysis of the effect of XBRL adoption on Korean capital markets can provide useful insights for countries considering XBRL adoption. In this study, we examine how changes in the financial information environment attributable to XBRL adoption affect the cost of capital.

Firms must incur higher expenses to adopt and maintain the new system. However, at the same time, they are able to reduce the costs associated with information asymmetry between management and outside information users through more timely and comparable information. XBRL adoption benefits information users through the provision of more customized data search and retrieval functions. Further, information users may view firms using XBRL as more transparent and as providing higher quality financial information; hence, users are more likely to evaluate such firms more favorably than those not using XBRL.

If financial information users-investors in particular-view XBRL adoption as good news, then they are willing to pay a higher price for shares of firms under the XBRL system. Therefore, in this study, we examine the association between XBRL adoption and the cost of capital. In addition, firms suffering from high information asymmetry are more likely to experience a greater benefit 
when the XBRL system is introduced. Thus, we also examine whether firms experiencing high information asymmetry experienced lower cost of capital than others on XBRL adoption. Meanwhile, XBRL adoption may also affect information producers from the perspective of information production efficiency. In order to examine the effect of the adoption on information production efficiency, this study investigates whether the adoption reduces reporting lags for both voluntary and mandatory filers. Also, we examine whether this reduction in reporting lags affects the cost of capital.

We find evidence that voluntary filers of XBRL experience a decrease in the cost of equity capital after XBRL adoption. The decrease in the cost of equity capital appears more pronounced for firms with higher information asymmetry. In the case of mandatory XBRL filers, similar reductions in the cost of equity capital are identified after the adoption. Together, these results suggest that XBRL adoption reduces the cost of capital regardless of the nature of adoption (i.e., voluntary and mandatory). In addition, we find evidence that reporting lags are reduced for both voluntary filers and mandatory filers after XBRL adoption, suggesting an improvement in information processing efficiency. We also find that a reduction in reporting lag causes reduction in the cost of capital. The results of this study suggest that the introduction of new information technology may benefit capital market participants by reducing their cost of capital via the improvement of timeliness of disclosure. This study provides useful insights to regulators and firms who are considering mandatorily or voluntarily adopting new information technology for their capital markets.

\section{Related Literature and Hypotheses Development}

\subsection{XBRL}

XBRL allows information users to process financial data on a real-time basis in their customized forms. Thus, unlike previous paper-based or HTML-based disclosure systems, XBRL offers information users a user-friendly way to search and retrieve relevant data. As information providers, firms can easily prepare, change, transfer, retrieve, and share financial information once they install the internationally standardized XBRL taxonomy. Under the XBRL taxonomy, each accounting item has its own tag that is internationally standardized. Thus, the XBRL tagging system is considered an object-oriented language. More specifically, XBRL is a flexible and comprehensive system that processes data and has the following characteristics.

1) Encapsulation: Each accounting item is defined as a unique class using a standardized tagging mechanism; hence, each item can be systematically processed.

2) Inheritance: By using established reusable codes, XBRL extends its function and enables the characteristics of a higher-class type within the taxonomy to transfer to those of lower-class types. Thus, a lower-class type shares the characteristics and functions of a higher-class type. 
3) Polymorphism: As an object-oriented language, XBRL has common commands that can achieve objects in various ways depending on the class type. For example, a supervisor orders two employees to arrange documents by using the same command code. However, each employee can conduct the same command in a different way. More specifically, under the same command, a way of realization may be different, and therefore, the results may not be the same.

Utilizing these characteristics, information users retrieve and use the processed data for their own purposes and with confidence that the accounting data possess common characteristics and a common structure.

\subsection{Related Literature and Hypotheses Development}

Reducing information asymmetry by improving the information environment surrounding the corporate world has been of significant interest to practitioners and researchers [1] [2] [3] [4]. Limitations in the accessibility of relevant information increase information asymmetry [5] [6] [7] [8] [9]. In an environment with limited accessibility to relevant information, information users incur more expenses owing to insufficient information. In addition, variations in accessibility across information users increase the likelihood of failure to achieve consensus [10]-[15]. Limitations on timely accessibility of relevant information increase the conflicts of interest between firms providing information and users of financial information, leading to the production of a different conclusion. A particular piece of information may receive over- or under-reaction from users given the information asymmetry [16] [17] [18] [19] [20]. XBRL was developed to solve problems associated with information asymmetry between financial information providers and users of information [21] [22] [23] [24] [25]. With XBRL, information users can access relevant information at lower costs and in a timely manner.

Before the adoption of XBRL, the HTML-based disclosure system required immense effort and significant time for retrieval of relevant information because it only provided plain-text format information owing to the limited ability of HTML to search for functions within texts. Moreover, HTML requires transferring manually collected data to a form that is compatible with the data analysis program. However, XBRL, with its standardized taxonomy and unique tags representing each accounting item, allows users to execute various commands to retrieve the information of interest from financial statements, including footnotes and supplementary schedules. In addition, the data retrieved using the XBRL system is compatible with various statistical analysis software packages such as Excel, SPSS, and SAS; furthermore, the data can reduce information processing time.

The costs associated with information production and acquisition can be significantly lower when information is compatible and processing time is reduced [26]. Because standardized information under the XBRL taxonomy allows users 
to easily retrieve relevant data and compare firms, the financial information provided by firms improves both transparency and integrity. In turn, such improvements reduce information asymmetry and the likelihood of prediction errors.

Chen, S., Harris, L., Li, W., \& Wu, D. [27] report that the cost of equity declined after XBRL adoption in China depending on state ownership level. Li, O., $\mathrm{Ni}, \mathrm{C}$., \& Lin, Y. [28] state that XBRL can reduce the delays and noise associated with the information production process by expanding information channels. Leuz, C., \& Verrecchia, R. [29] indicate that voluntary adoption of an enhanced financial disclosure system can be interpreted as a positive signal of management's willingness to disclose high-quality information to investors.

We note that the cost of capital is one of the most important concerns of management. The cost of capital is determined by the likelihood of failing to recover an investment and generating expected returns [30] [31] [32] [33]. To rationally and accurately determine the cost of capital, investors must gain relevant information to assess firms' solvency and credit risk. If a restriction exists on access to relevant information or if the information is not transparent, investors evaluate a higher risk and increase the risk premium, which in turn increases the cost of capital to firms issuing the stocks [13] [34] [35]. Firms issuing stocks are likely to voluntarily adopt XBRL to improve accessibility and reduce the cost of capital. Healy, P., \& Palepu, K. [36] and Myers, S., \& Majluf, N. [37] also argue that management has an incentive to voluntarily disclose information to reduce the information asymmetry between themselves and investors and eventually reduce the resulting cost of capital. Pinsker, R., \& Li, S. [38] mention that XBRL also leads to lower operating costs to produce information; in addition, XBRL provides a "first-mover" advantage to voluntary XBRL filers in the market (e.g., reduced costs of capital). Based on this discussion, we develop the following hypothesis in the alternative form to relate voluntary XBRL adoption to the cost of capital.

Hypothesis 1: The cost of equity capital for voluntary XBRL filers decreases after adoption.

Healy, P., \& Palepu, K. [36] state that information processing costs decline if a common language-facilitating more effective communication among information providers and users - is available for disclosure rules on financial statements. Although no guarantee exists that firms disclose more information under the XBRL system, XBRL enhances accessibility through comparable and standardized accounting information. With better accessibility, both the standardized reporting language and the system reduce the information asymmetry between firms and financial information users. Further, an improved information environment gives investors access better opportunities and increases stock liquidity [36]. An improved information environment also provides minority shareholders in a vulnerable position with relatively greater benefits [39].

When firms voluntarily decide to adopt a new advanced technology, such as 
XBRL, they must bear all of the costs associated with the adoption and settlement. At the same time, firms with greater information asymmetry due to a poor information environment are more likely to experience a greater benefit via the adoption of XBRL [40]. Moreover, firms with greater information asymmetry must incur higher expenses because of the necessity to improve information environment and monitor the quality of information. Thus, the effect of voluntary XBRL adoption on the cost of capital to be more pronounced when information asymmetry is greater. On the basis of this discussion, we develop Hypothesis 2 in an alternative form to relate voluntary XBRL adoption with higher information asymmetry and the cost of capital.

Hypothesis 2: On voluntary adoption, the cost of equity capital of XBRL filers with higher information asymmetry decreases more than that of XBRL filers with lower information asymmetry.

The effect of voluntary XBRL adoption on the reduction in information asymmetry would be greater than mandatory XBRL adoption because voluntary adoption may represent management's intention to improve disclosure quality [29]. In addition, voluntary adoption can be interpreted as the outcome of effective corporate governance in capital markets [41]. Kim, J., \& Shi, H. [42] report that voluntary IFRS adopters experience an increase in the number of analysts following and an improvement in analyst forecast accuracy. Their findings are consistent with the notion of an improved information environment. Previous studies also report that the amount of voluntary disclosure reduces the cost of capital [43] [44] and improves the predictability and value relevance of the accounting information [45] [46]. Consistent with these studies, Daske, H., Hail, L., \& Leuz, C., \& Verdi, R. [47] report that firms that voluntarily adopt IFRS experience a more positive effect on firm value than those that adopt IFRS for a first-time mandate.

The effect of voluntary XBRL adoption may be different from that of IFRS because the adoption itself does not increase the amount of information but, rather, improves information visibility and accessibility [28]. In addtion, the XBRL operating environment in the United States and Korea may not be the same. For example, the United States initiated VFP in 2005, and mandated XBRL filing in 2009 for firms with more than $\$ 5$ billion and in 2011 for the remaining public firms. By contrast, in Korea, XBRL filing was mandated for all public firms after one year of voluntary adoption. More specifically, a four-year time difference existed from VFP to the first mandatory adoption in the United States, whereas only one year existed after the VFP implementation in Korea. Thus, US firms had relatively sufficient time to acquire the necessary knowledge to effectively implement and utilize XBRL. However, the one-year period in Korea after the implementation of VFP may not have been sufficient to differentiate the effect of voluntary and mandatory XBRL filings. Thus, the effect of the adoption on the capital markets may not differ significantly for mandatory adopters in 2007 and for voluntary adopters in 2006 in Korea. By studying Korean case, those contries considering a prompt XBRL adoption over a short time period can gain useful 
insights for their policy decision. Given this discussion, we develop the following null hypothesis to relate voluntary XBRL adoption relative to mandatory adoption to the cost of capital.

Hypothesis 3: After the adoption of the mandatory XBRL filing program, the decreasing cost of equity capital of voluntary XBRL filers is the same as that of mandatory XBRL filers.

\section{Research Model and Sample Selection}

\subsection{Research Model}

Managers tend to reduce the possibility of adverse selection and the cost of capital through disclosures. Healy, P., \& Palepu, K. [36] state that the technological innovation in a firm's financial reporting system engenders the creation of a new communication channel among investors and reduces the cost of voluntary information disclosures. Advancements in internet-based reporting systems increase the quality of information disclosures. Therefore, introducing an innovative voluntary disclosure system based on XBRL reduces the cost of information for investors and ultimately reduces a firm's cost of capital. To test Hypothesis 1, the following empirical model is used.

$$
\begin{aligned}
& \text { CEC_PEG }(\text { CEC_MPEG or CEC_GM })_{i t} \\
& =\alpha_{i t}+\beta_{1} V O L P O S T_{i t}+\beta_{2} \text { BETA }_{i t}+\beta_{3} S_{Z I E_{i t}}+\beta_{4} M T B_{i t} \\
& \quad+\beta_{5} R D E B T_{i t}+\beta_{6} R O A_{i t}+\beta_{7} P_{I I S T_{i t}}+\sum \beta_{7+i} D I N D_{i t}+\varepsilon_{i t}
\end{aligned}
$$

(Hypothesis 1, see Table 1, Panel A)

where,

CEC_PEG (CEC_MPEG/CEC_GM): a proxy for firms' cost of equity capital as suggested in [32] and [48];

VOLPOST (MANDPOST): 1 if the sample year is after voluntary (mandatory) $\mathrm{XBRL}$ adoption, and 0 otherwise;

BETA: estimated beta ( $\beta$ ) from the Capital Asset Pricing Model (CAPM);

SIZE: natural logarithm of the firm's equity market capitalization at the end of the lagged year;

$M T B$ : total market value ${ }_{t-1}$ scaled by the book value of total equity capital $t_{t-1}$;

$R D E B T$ : total debt to total assets ratio;

$R O A$ : net income scaled by total assets;

PLIST: natural logarithm of the number of years since a firm was listed on the markets; and,

DIND: dummy variables to control the effects of industries.

Gode, D., \& Mohanram, P. [32] use analysts' forecast data to estimate the cost of capital, whereas Easton, P. [48] estimates the cost of capital using a model assuming continuous growth and no dividends. Ohlson, J., \& Juettner-Nautoth, B. [49] use the current price, forthcoming and two-year-ahead earnings per shares, forthcoming dividends per share, and a perpetual growth rate to estimate the risk premium without needing to forecast book value (hereafter the OJ model). Gode, 
Table 1. Effect on cost of capital for mandatory vs. voluntary XBRL adopters. (a) 1:1 matching sample; (b) 1:2 matching sample.

(a)

\begin{tabular}{|c|c|c|c|c|c|c|c|c|c|c|c|c|c|c|c|c|c|c|c|}
\hline & \multirow[t]{2}{*}{ Dependent } & \multicolumn{6}{|c|}{$C E C \_P E G$} & \multicolumn{6}{|c|}{$C E C_{-} G M$} & \multicolumn{6}{|c|}{$C E C \_M P E G$} \\
\hline & & Coeff. & t-val & & Coeff. & t-val & & Coeff. & t-val & & Coeff. & t-val & & Coeff. & t-val & & Coeff. & t-val & \\
\hline$\beta_{0}$ & INTERCPT & 0.9640 & 6.84 & $* * *$ & 0.9635 & 6.79 & $* * *$ & 0.9893 & 6.59 & $* * *$ & 0.9900 & 6.55 & $* * *$ & 0.9799 & 6.51 & $* * *$ & 0.9826 & 6.49 & $* * *$ \\
\hline$\beta_{1}$ & $M A N D P O S T$ & -0.0241 & -2.57 & $* *$ & -0.0265 & -1.96 & * & -0.0289 & -2.89 & $* * *$ & -0.0319 & -2.21 & $* *$ & -0.0312 & -3.11 & $* * *$ & -0.0385 & -2.67 & $* * *$ \\
\hline$\beta_{2}$ & $V O L X B R L$ & & & & -0.0007 & -0.05 & & & & & -0.0026 & -0.17 & & & & & -0.0078 & -0.51 & \\
\hline$\beta_{3}$ & $\begin{array}{c}\text { VOLXBRL } \\
{ }^{*} M A N D P O S T\end{array}$ & & & & 0.0043 & 0.24 & & & & & 0.0055 & 0.29 & & & & & 0.0135 & 0.71 & \\
\hline$\beta_{4}$ & $B E T A$ & 0.0074 & 0.65 & & 0.0084 & 0.69 & & 0.0067 & 0.55 & & 0.0075 & 0.58 & & 0.0080 & 0.66 & & 0.0096 & 0.75 & \\
\hline$\beta_{5}$ & $S I Z E$ & -0.0332 & -6.88 & $* * *$ & -0.0332 & -6.83 & $* * *$ & -0.0331 & -6.44 & $* * *$ & -0.0331 & -6.39 & $* * *$ & -0.0328 & -6.37 & $* * *$ & -0.0327 & -6.31 & $* * *$ \\
\hline$\beta_{6}$ & $M T B$ & -0.0127 & -4.90 & $* * *$ & -0.0128 & -4.72 & $* * *$ & -0.0140 & -5.04 & $* * *$ & -0.0139 & -4.82 & $* * *$ & -0.0155 & -5.58 & $* * *$ & -0.0154 & -5.31 & $* * *$ \\
\hline$\beta_{7}$ & $R D E B T$ & 0.2856 & 8.47 & $* * *$ & 0.2862 & 7.78 & $* * *$ & 0.2944 & 8.20 & $* * *$ & 0.2931 & 7.48 & $* * *$ & 0.2981 & 8.28 & $* * *$ & 0.2934 & 7.48 & $* * *$ \\
\hline$\beta_{8}$ & $R O A$ & 0.2003 & 2.32 & $* *$ & 0.1996 & 2.25 & $* *$ & 0.2119 & 2.30 & $* *$ & 0.2088 & 2.21 & $* *$ & 0.2604 & 2.82 & $* * *$ & 0.2509 & 2.65 & $* * *$ \\
\hline$\beta_{9}$ & $P L I S T$ & 0.0094 & 1.32 & & 0.0094 & 1.31 & & 0.0103 & 1.35 & & 0.0103 & 1.34 & & 0.0098 & 1.28 & & 0.0097 & 1.27 & \\
\hline \multirow[t]{4}{*}{$\beta_{10}$} & $D I N D$ & Inclu & uded & & Inclu & uded & & & luded & & & luded & & & luded & & & luded & \\
\hline & F & & 15.15 & $* * *$ & & 13.24 & $* * *$ & & 14.89 & $* * *$ & & 13.01 & $* * *$ & & 15.97 & $* * *$ & & 14.01 & $* * *$ \\
\hline & Adj. $R^{2}$ & & $50 \%$ & & & $49 \%$ & & & $49 \%$ & & & $49 \%$ & & & $51 \%$ & & & $51 \%$ & \\
\hline & $\mathbf{N}$ & & 216 & & & 216 & & & 216 & & & 216 & & & 216 & & & 216 & \\
\hline$\beta_{1}+\beta_{3}$ & & & & & -0.0222 & 3.16 & * & & & & -0.0264 & 3.94 & $* *$ & & & & -0.0250 & 3.52 & * \\
\hline
\end{tabular}

(b)

\begin{tabular}{|c|c|c|c|c|c|c|c|c|c|c|c|c|c|c|c|c|c|c|c|}
\hline & \multirow[t]{2}{*}{ Dependent } & \multicolumn{3}{|l|}{$C E C \_P E G$} & \multicolumn{3}{|c|}{$C E C \_P E G$} & \multicolumn{3}{|c|}{$C E C \_G M$} & \multicolumn{3}{|c|}{$C E C \_G M$} & \multicolumn{3}{|c|}{$C E C \_M P E G$} & \multicolumn{3}{|c|}{$C E C \_M P E G$} \\
\hline & & Coeff. & t-val & & Coeff. & t-val & & Coeff. & t-val & & Coeff. & t-val & & Coeff. & t-val & & Coeff. & t-val & \\
\hline$\beta_{0}$ & $I N T E R C P T$ & 0.9439 & 8.28 & $* * *$ & 0.9318 & 8.16 & $* * *$ & 1.0043 & 8.24 & $* * *$ & 0.9905 & 8.12 & $* * *$ & 1.0186 & 8.20 & $* * *$ & 1.0055 & 8.08 & $* * *$ \\
\hline$\beta_{1}$ & $M A N D P O S T$ & -0.0161 & -2.16 & $* *$ & -0.0121 & -1.33 & & -0.0202 & -2.54 & $* *$ & -0.0169 & -1.74 & * & -0.0215 & -2.65 & * & -0.0197 & -1.99 & $* *$ \\
\hline$\beta_{2}$ & $V O L X B R L$ & & & & 0.0180 & 1.53 & & & & & 0.0193 & 1.54 & & & & & 0.0169 & 1.32 & \\
\hline$\beta_{3}$, & $\begin{array}{c}\text { VOLXBRL } \\
{ }^{*} M A N D P O S T\end{array}$ & & & & -0.0113 & -0.76 & & & & & -0.0095 & -0.59 & & & & & -0.0051 & -0.31 & \\
\hline$\beta_{4}$ & $B E T A$ & 0.0214 & 2.46 & $* *$ & 0.0226 & 2.55 & $* *$ & 0.0200 & 2.15 & $* *$ & 0.0216 & 2.28 & $* *$ & 0.0191 & 2.01 & $* *$ & 0.0209 & 2.16 & $* *$ \\
\hline$\beta_{5}$ & $S I Z E$ & -0.0327 & -8.40 & $* * *$ & -0.0329 & -8.47 & $* * *$ & -0.0337 & -8.11 & $* * *$ & -0.0340 & -8.19 & $* * *$ & -0.0342 & -8.09 & $* * *$ & -0.0345 & -8.15 & $* * *$ \\
\hline$\beta_{6}$ & $M T B$ & -0.0123 & -5.63 & $* * *$ & -0.0130 & -5.79 & $* * *$ & -0.0138 & -5.92 & $* * *$ & -0.0147 & -6.12 & $* * *$ & -0.0153 & -6.46 & $* * *$ & -0.0162 & -6.62 & $* * *$ \\
\hline$\beta_{7}$ & $R D E B T$ & 0.2756 & 9.52 & $* * *$ & 0.2884 & 9.57 & $* * *$ & 0.2937 & 9.50 & $* * *$ & 0.3082 & 9.57 & $* * *$ & 0.2956 & 9.38 & $* * *$ & 0.3094 & 9.42 & $* * *$ \\
\hline$\beta_{8}$ & $R O A$ & 0.1702 & 2.10 & $* *$ & 0.1932 & 2.35 & $* *$ & 0.1595 & 1.84 & * & 0.1852 & 2.11 & $* *$ & 0.2114 & 2.40 & $* *$ & 0.2353 & 2.62 & $* * *$ \\
\hline$\beta_{9}$ & PLIST & 0.0093 & 1.65 & & 0.0098 & 1.74 & * & 0.0088 & 1.46 & & 0.0094 & 1.56 & & 0.0084 & 1.37 & & 0.0089 & 1.46 & \\
\hline \multirow[t]{4}{*}{$\beta_{10}$} & $D I N D$ & Inclu & ded & & Incl & ided & & & cluded & & & cluded & & & luded & & & luded & \\
\hline & F & & 17.50 & $* * *$ & & 15.61 & $* * *$ & & 17.81 & $* * *$ & & 15.90 & $* * *$ & & 18.14 & $* * *$ & & 16.14 & $* * *$ \\
\hline & Adj. $R^{2}$ & & $48 \%$ & & & $48 \%$ & & & $48 \%$ & & & $49 \%$ & & & $49 \%$ & & & $49 \%$ & \\
\hline & $\mathrm{N}$ & & 276 & & & 276 & & & 276 & & & 276 & & & 276 & & & 276 & \\
\hline$\beta_{1}+\beta_{3}$ & & & & & -0.0234 & 3.69 & * & & & & -0.0264 & 4.13 & $* *$ & & & & -0.0248 & 3.51 & * \\
\hline
\end{tabular}

Note: See Appendix for variable definitions. ${ }^{* *},{ }^{* *}$, and ${ }^{*}$ represent significance at the $1 \%, 5 \%$, and $10 \%$ levels, respectively, in two-tailed tests. 
D., \& Mohanram, P. [32] take the logic of the OJ model one step further and compare it with other estimation measures of the risk premium using implementations of the residual income valuation model. They find the robustness of the OJ model by estimating the risk premium. Following [32] method, we derive a firm's cost of equity capital (hereafter $C E C_{-} G M$ ):

Easton, P. [48] develops an estimation risk premium model on the basis of the PEG ratio, which is the PE ratio divided by the short-term earnings growth rate, and the modified PEG ratio. The PEG ratio strongly presumes that the expected dividend per share and the expected abnormal growth in accounting earnings equal zero, such that the only data required for the estimation are earnings growth and price (hereafter $C E C_{-} P E G$ ). However, in the estimation process with the modified PEG model, Easton, P. [48] relaxes the strong assumption that the expected dividend per share equals zero (hereafter CEC_MPEG).

We use these three methodologies to estimate the sample firms' cost of equity capital (CEC_GM/CEC_PEG/CEC_MPEG). Because providing the estimation process of the cost of equity capital is not this study's intention, we simply use the methodologies proposed by Gode, D., \& Mohanram, P. [32] and Easton, P. [48], and check the effects of the (voluntary/mandatory) XBRL filing on the cost of equity capital. The test variable used in this study is VOLPOST, representing the years after voluntary XBRL adoption.

As control variables, we consider several firm characteristics. First, we include BETA to represent the structural riskiness of each firm as estimated by the CAPM because previous studies report a negative correlation between BETA and the cost of capital [50] [51]. Firm size (SIZE) is included because large firms experience relatively low asymmetric information [30] [32] [52]. Firms with a high market to book value $(M T B)$ show a higher stock price return [53]. Therefore, we predict that $S I Z E$ and $M T B$ are negatively correlated with the cost of capital. Firms with a high debt ratio ( $R D E B T)$ have a high risk of bankruptcy and, hence, experience a high cost of capital [33] [54]. Profitable firms are expected to experience lower costs of equity capital. Firms with a longer history are expected to experience a lower cost of capital. Thus, we include return on assets $(R O A)$ and the natural logarithm of the number of years after public listing (PLIST) [55].

Firms with higher information asymmetry experience higher costs of capital. Thus, improved information transparency after XBRL adoption is expected to reduce the cost of capital. Previous studies (e.g., [29] [56] [57] [58] use bid-ask spreads as a proxy for information asymmetry. A bid-ask spread is the price difference divided by the average of two prices-the ask price preference and the bid price preference-of the firm. We categorize the sample into two groups: firms with high and low asymmetric information. We define the high information asymmetry group as firms with a spread price higher than the median and the low group as firms with a spread price lower than or equal to the median (i.e., HIGHSPREAD is 1 for firms with a spread price higher than the median, and 0 otherwise). We include an interaction variable, VOLPOST ${ }^{*} H I G H S P R E A D$, in 
the model to test whether firms with high asymmetric information experience a larger decrease in the cost of capital after voluntary XBRL adoption (VOLPOST). To test Hypothesis 2, we utilize the following empirical model.

$$
\begin{aligned}
& \text { CEC_PEG }\left(C E C \_G M \text { or CEC_MPEG }\right)_{i t} \\
& =\alpha_{i t}+\beta_{1} \text { VOLPOST } T_{i t}+\beta_{2} \text { HIGHSPREAD }_{i t}+\beta_{3} \text { VOLPOST } * \text { HIGHSPREAD } \\
& +\beta_{4} B E T A_{i t}+\beta_{5} S I Z E_{i t}+\beta_{6} M T B_{i t}+\beta_{7} R D E B T_{i t} \\
& +\beta_{8} R O A_{i t}+\beta_{9} P L I S T_{i t}+\sum \beta_{10+i} D I N D_{i t}+\varepsilon_{i t}
\end{aligned}
$$

where,

CEC_PEG (CEC_MPEG/CEC_GM): a proxy for firms' cost of equity capital as suggested in [32] and [48];

VOLPOST: 1 if the sample year is after voluntary XBRL adoption and 0 otherwise;

HIGHSPREAD: 1 if the natural logarithm of a firm's bid-ask spread is larger than the sample median, and 0 otherwise;

$B E T A$ : estimated beta $(\beta)$ from the CAPM;

$S I Z E$ : natural logarithm of the firm's equity market capitalization at the end of the lagged year;

$M T B$ : total market value t-1 $_{1}$ scaled by the book value of total equity capital ; $_{t-1}$;

$R D E B T$ : total debt to total assets ratio;

$R O A$ : net income scaled by total assets;

PLIST: natural logarithm of the number of years since a firm was listed on the markets; and

DIND: dummy variables to control the effects of industries.

In Korea, all listed firms have been required to adopt the XBRL system since 2007. Firms that voluntarily adopted XBRL my not experience any incremental benefit in their cost of equity capital during the year of mandatory adoption because the effect of an improved information environment has already been reflected in their cost of capital at the time they initially introduced the system. In contrast, mandatory adoption firms can benefit from a change in their information environment on their initial XBRL disclosure after adoption. Then, firms that adopted XBRL during the mandatory adoption are expected to experience a greater decrease in the cost of capital relative to voluntary adoption firms. The following empirical model is used to test Hypothesis 3.

$$
\begin{aligned}
& C E C_{-} P E G\left(C E C_{-} G M \text { or CEC_MPEG }\right)_{i t} \\
& =\alpha_{i t}+\beta_{1} M_{A N D P O S T}+\beta_{2} V_{\text {VOLXBR }}+\beta_{3} \text { VOLXBRL }_{i t} \text { MANDPOST }_{i t} \\
& +\beta_{4} B_{E T A_{i t}}+\beta_{5} S I Z E_{i t}+\beta_{6} M T B_{i t}+\beta_{7} R D E B T_{i t} \\
& +\beta_{8} R O A_{i t}+\beta_{9} P_{L I S T}+\sum \beta_{10+i} D I N D_{i t}+\varepsilon_{i t}
\end{aligned}
$$

where,

CEC_PEG (CEC_MPEG/CEC_GM): a proxy for firms' cost of equity capital as suggested in [32] and [48];

MANDPOST: 1 for years of mandatory XBRL adoption (2008 and 2009), and 0 otherwise (2005 and 2006); 
VOLXBRL: 1 if firms voluntarily adopted XBRL before the year of mandatory adoption, and 0 otherwise;

BETA: estimated beta $(\beta)$ from the CAPM;

SIZE: natural logarithm of the firm's equity market capitalization at the end of the lagged year;

$M T B$ : total market value $t_{t-1}$ scaled by the book value of total equity capital $t_{t-1}$;

$R D E B T$ : total debt to total assets ratio;

$R O A$ : net income scaled by total assets;

PLIST: natural logarithm of the number of years since a firm was listed on the markets; and

DIND: dummy variables to control the effects of industries.

\subsection{Sample Selection}

Initial sample consists of $502 \mathrm{KSE}$ and KOSDAQ (Korea Securities Dealers Automated Quotations) listed firms that participated in the VFP in 2006. We set the sample period to four years around 2006, when VFP was initiated: two years before (2004 and 2005) and two years after (2007 and 2008) XBRL. The sample excludes the transition year 2006 from the sample to minimize a possible confounding effect. Among the voluntary filers during these pre- and post-periods, the sample excludes firms that meet the following criteria: 1) non-financial industries; 2) firms for which data are unavailable to estimate the cost of equity capital; 3) firms for which data are unavailable to calculate bid-ask spreads; and 4) firms for which data are unavailable for control variables. We then require that, for the sample firms for four years (pre- and post-periods), all of the variables in the regression be available. These criteria resulted in a total of 152 firm-year observations: 76 observations before and 76 observations after. The sample represents 25 industries. There is no clustering in a specific industry. The most frequent sample is from pharmaceuticals industry represeting 16 observations. We use the FN-GUIDE and TS-2000 databases for the analyst forecasts and financial data in the empirical model. The FN-GUIDE database provides information on analysts' forecasts with financial statement data. The bid and ask prices for the bid-ask spreads were extracted from the KOSCOM database. The KOSCOM database provides stock and option prices beginning in the 1970s.

For Hypothesis 3, another four-year sample period is set around 2007, the first year of mandatory adoption: two years before (2005 and 2006) and two years after (2008 and 2009) the mandatory adoption. We also exclude the transition year 2007 from the sample to avoid any contaminating effects. We then require that all variables used in the regression be available for the firms in the sample.

To observe and compare changes in the voluntary and mandatory filers after the mandatory adoption, we structure the sample group in two ways. First, we adopt the "1:1 voluntary-to-mandatory" ratio. Through the sampling process with the criteria previously presented, we acquired 216 firm-year samples of mandatory and voluntary filers that are similar in firm size within the industry 
for the pre- and post-mandatory periods (four years). Second, we consider the issue of a "good target-to-matching sample ratio following [59]. We select "1:2 voluntary-to-mandatory" sample firms with similar firm sizes in the same industry.

\section{Results and Empirical Analyses}

\subsection{Descriptive Statistics}

Table 2 presents the descriptive statistics of the variables during the entire sample period. Three estimated values of firms' cost of equity capital (CEC_PEG, CEC_GM, and CEC_MPEG) have a mean value range from 0.1563 to 0.1741 . The median values are between 0.1354 and 0.1527 and are slightly lower than the mean values. The variations in the three estimated values of the cost of equity capital over the industries are statistically significant. The mean and median values of firms' sizes $(S I Z E)$ are very similar, at 27.8682 and 27.4420 , respectively. Both the firms' debt ratio and $R O A$ mean values are approximately $43 \%$ and $6 \%$, respectively; further, the market values of the sample firms are 1.84 times the mean value and 1.25 times the median value of their book values.

To test the differences in the variables between these two periods, we classify the sample period into two parts: pre-XBRL (2004 and 2005) and post-XBRL (2007 and 2008) regarding the VFP. Table 3 presents the results of the difference tests using the variables' mean/median values. First, firms' cost of equity capital ( $C E C_{-} P E G, C E C_{-} G M$, and $C E C_{-} M P E G$ ) significantly decreased after voluntary XBRL adoption $(t=3.82-4.29)$. Further, all differences in the mean values of the cost of capital estimates between pre- and post-XBRL are significant at the 1 percent level. With respect to their median values, we find similar results; for example, the median value of $C E C_{-} M P E G$ significantly declined by approximately 0.0390 points after firms' participation in the VFP. Other median values also show significant changes in firms' cost of equity capital after XBRL. Other control variables, including firm size (SIZE), debt ratio (RDEBT), and profitability $(R O A)$, show no statistical differences during these two periods; however, the market-to-book $(M T B)$ ratio significantly increased twice after XBRL adoption $(\mathrm{t}$ $\left.=-3.47^{* * *}, \mathrm{z}=-2.26^{* * *}\right)$.

The correlations (untabulated) among the estimated cost of equity capital (CEC_PEG, CEC_GM, and CEC_MPEG) are more than 98 percent and are very significant at the 1 percent level, suggesting that the validity of these estimates is supported. Firm size (SIZE) and firms' listed period show no relationships with their cost of equity capital measures. In particular, the finding that no relationship exists between the listed period and the cost of capital is inconsistent with the expectation because previous studies find that the more established firms experience a lower level of information asymmetry [60] [61] [62]. However, firms with a higher risk $(B E T A)$ and debt ratio $(R D E B T)$ reveal a higher cost of equity capital. Furthermore, the market-to-book ratio $(M T B)$ and profitability $(R O A)$ show significant and negative correlations with the cost of equity capital, suggesting 
Table 2. Descriptive statistics.

\begin{tabular}{ccccccccc}
\hline & Min & Q1 & Mean & Median & Q3 & Max & Std. & N \\
\hline CEC_PEG & 0.0410 & 0.1048 & 0.1563 & 0.1354 & 0.1847 & 0.4367 & 0.0758 & 152 \\
& & & & & F-test (Industry): & $9.74^{* * *}$ & \\
CEC_GM & 0.0592 & 0.1229 & 0.1741 & 0.1516 & 0.2050 & 0.4747 & 0.0790 & 152 \\
& & & & & F-test (Industry): & $9.28^{* * *}$ & \\
CEC_MPEG & 0.0424 & 0.1173 & 0.1725 & 0.1527 & 0.2033 & 0.4828 & 0.0817 & 152 \\
& & & & & F-test (Industry): & $9.18^{* * *}$ & \\
BETA & 0.0083 & 0.6149 & 0.9191 & 0.9593 & 1.1601 & 2.1141 & 0.4269 & 152 \\
SIZE & 25.4420 & 26.6639 & 27.8682 & 27.4420 & 28.7181 & 31.7826 & 1.4994 & 152 \\
MTB & 0.2191 & 0.7405 & 1.8396 & 1.2460 & 2.2810 & 14.1227 & 1.9781 & 152 \\
RDEBT & 0.0844 & 0.3174 & 0.4331 & 0.4141 & 0.5880 & 0.8677 & 0.1851 & 152 \\
ROA & -0.1827 & 0.0242 & 0.0588 & 0.0557 & 0.0801 & 0.3454 & 0.0630 & 152 \\
PLIST & 0.0000 & 2.0794 & 2.6338 & 2.9444 & 3.4340 & 3.8286 & 0.9757 & 152 \\
\hline
\end{tabular}

Note: See Appendix for variable definitions. ${ }^{* *},{ }^{* *}$, and ${ }^{*}$ represent significance at the $1 \%, 5 \%$, and $10 \%$ levels, respectively, in two-tailed tests.

Table 3. Univariate comparisons between pre- and post-XBRL periods.

\begin{tabular}{|c|c|c|c|c|c|c|c|c|}
\hline & \multicolumn{4}{|c|}{ Mean } & \multicolumn{4}{|c|}{ Median } \\
\hline & Pre & Post & \multicolumn{2}{|c|}{$t$-value } & Pre & Post & \multicolumn{2}{|c|}{ z-value } \\
\hline $\mathbf{N}$ & 76 & 76 & & & 76 & 76 & & \\
\hline$C E C \_P E G$ & 0.1788 & 0.1338 & 3.82 & $* * *$ & 0.1559 & 0.1249 & 3.56 & $* * *$ \\
\hline$C E C_{-} G M$ & 0.1984 & 0.1498 & 3.97 & $* * *$ & 0.1746 & 0.1384 & 3.23 & $* * *$ \\
\hline$C E C \_M P E G$ & 0.1994 & 0.1455 & 4.29 & $* * *$ & 0.1750 & 0.1360 & 3.56 & $* * *$ \\
\hline$B E T A$ & 0.9143 & 0.9239 & -0.14 & & 1.0200 & 0.7883 & 1.94 & * \\
\hline$S I Z E$ & 27.7404 & 27.9960 & -1.05 & & 27.2373 & 27.6104 & -1.29 & \\
\hline$M T B$ & 1.3017 & 2.3775 & -3.47 & $* * *$ & 1.0337 & 1.4982 & -2.26 & $* *$ \\
\hline$R D E B T$ & 0.4262 & 0.4400 & -0.46 & & 0.4220 & 0.4071 & 0.32 & \\
\hline$R O A$ & 0.0638 & 0.0539 & 0.96 & & 0.0606 & 0.0463 & 1.62 & \\
\hline PLIST & 2.4895 & 2.7781 & -1.84 & * & 2.8618 & 3.0201 & -0.87 & \\
\hline
\end{tabular}

Note: See Appendix for variable definitions. ${ }^{* *},{ }^{* *}$, and ${ }^{*}$ represent significance at the $1 \%, 5 \%$, and $10 \%$ levels, respectively, in two-tailed tests.

that greater growth potential and higher firm profitability help reduce the cost of capital. The hightest correlation between independent variables is -0.4891 between MTB and PLIST. Dropping one of these variables does not change our conclusion.

\subsection{Results of Empirical Analyses}

We test hypotheses using the three empirical models discussed in the previous 
section. Panel A of Table 4 presents the results of the first regression analysis using model (1) for Hypothesis 1. The coefficients of VOLPOST show the post-XBRL period effects on the cost of equity capital, which are negative and significant at the 1 percent level (range between -0.0335 and -0.0381). This result indicates that the cost of equity capital declined after XBRL adoption. Large-sized firms and firms with greater growth potential demonstrate lower cost of equity capital $\left(\right.$ SIZE $\left.=-0.0113--0.0123^{\star * *}, M T B=-0.0085^{\star}--0.0116^{\star *}\right)$. Firms' debt ratio $(R D E B T)$ also conveys positive and significant coefficient values under 1 percent, implying that "the higher the dependence on debt, the higher the cost of equity capital." BETA is negative and not significant using any cost of capital measures, a result that is inconsistent with the expectations but consistent with Cha, S., Chung, J., \& Yoo, Y. [52], who study the features that affect the cost of equity capital in the Korean market.

Next, Panel B of Table 4 shows a larger reduction in the cost of equity capital after XBRL adoption through the VFP for firms with higher information asymmetry. The level of information asymmetry was measured using bid-ask spreads. Consistent with the expectation, firms with high information asymmetry (HIGHSPREAD, higher bid-ask spreads) show a higher cost of equity capital ( $\mathrm{t}=$ $\left.1.96^{\star}-2.42^{\star *}\right)$. These firms experienced larger declines in the cost of equity capital than those with low information asymmetry (VOLPOST ${ }^{\star}$ HIGHSPREAD, $\mathrm{t}=$ $\left.-2.56^{* *}--2.98^{\star * *}\right)$. Therefore, this result indicates that the cost of equity capital declined incrementally after voluntary XBRL adoption.

When the auhors conducted the same analysis using the scale value of bid-ask spreads (SPREAD), we found that a possible multicollinearity problem existed between VOLPOST and the interaction term of VOLPOST with bid-ask spreads (VOLPOST`SPREAD), indicating that bid-ask spreads also changed after XBRL adoption. For this reason, we used the dummy variable of bid-ask spreads instead of bid-ask spreads to capture the level of information asymmetry. The dummy variable, HIGHSPREAD, has a value 1 if a firm's bid-ask spread is greater than each year's median value of the bid-ask spreads. Nonetheless, we checked the results of the regression analysis using bid-ask spreads and attained results similar to those in Panel B, Table 4. The maximum VIF (variance inflation factor) value was reported at approximately 3.8 , suggesting no severe multicollinearity problems. However, a strong correlation between VOLPOST and VOLPOST ${ }^{\star}$ SPREAD suggests possible changes in the level of bid-ask spreads after XBRL adoption, and VOLPOST almost explains these changes. That is, bid spreads also declined after XBRL adoption. Therefore, we need to understand that reducing information asymmetry leads to a reduction in the cost of capital. For this, a two-stage model should be considered to check reductions in the cost of equity capital through reductions in information asymmetry. 2SLS found that the level of information asymmetry significantly decreased after XBRL adoption $\left(t=-1.99^{* *}\right)$ and provided the same results as in Table 4, despite controlling for changes in bid-ask spreads. The first and second hypotheses ( $\mathrm{H} 1$ and $\mathrm{H} 2)$ are supported by these empirical results. 
Table 4. Effect on cost of capital for voluntary XBRL adopters. (a) Cost of equity capital; (b) Cost of equity capital with information asymmetry.

(a)

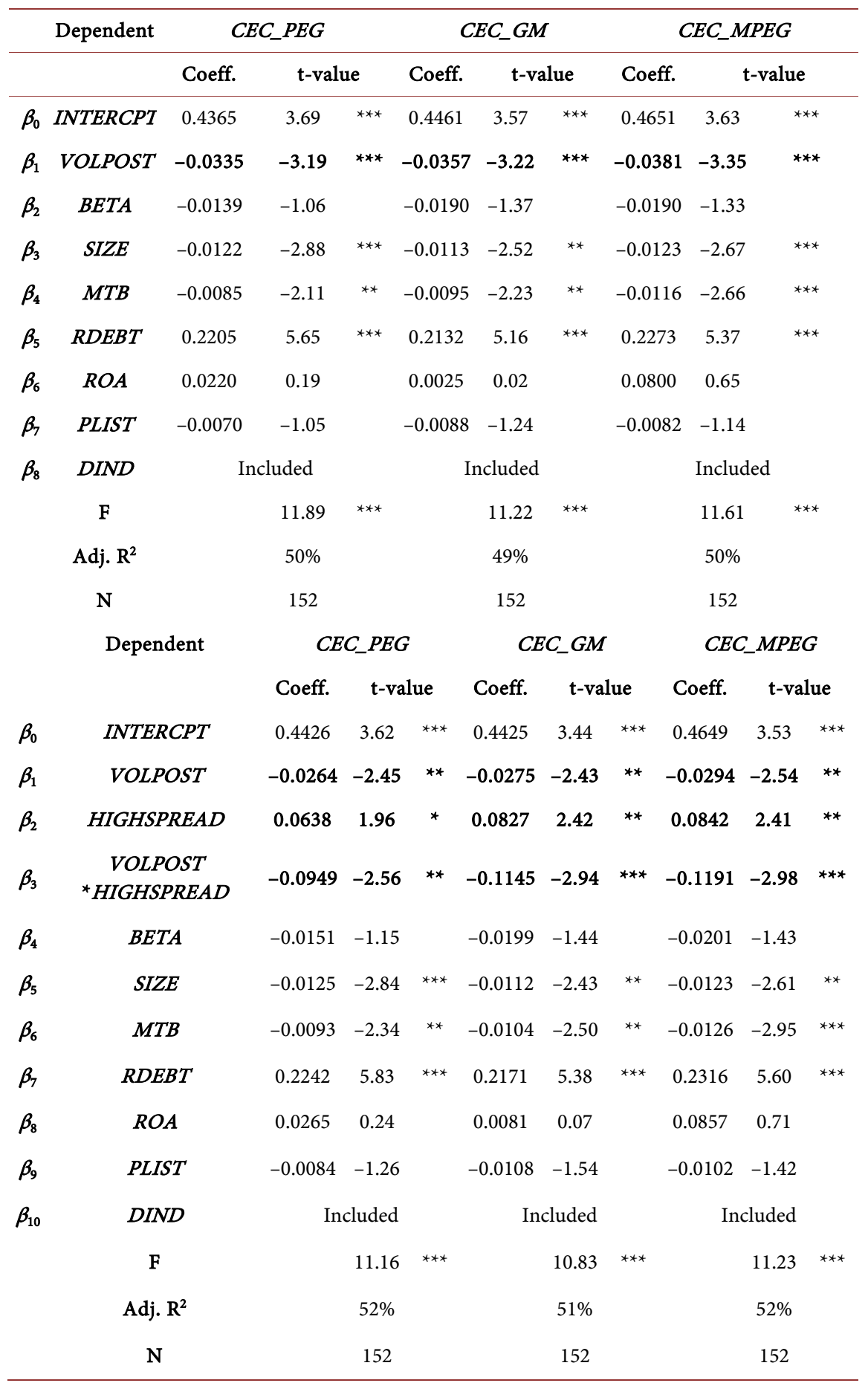

(b)

\begin{tabular}{ccccccccccc}
\hline & Dependent & \multicolumn{2}{c}{$C E C_{-} P E G$} & \multicolumn{2}{c}{$C E C_{-} G M$} & \multicolumn{3}{c}{$C E C_{-} M P E G$} \\
\hline & Coeff. & t-value & Coeff. & t-value & Coeff. & t-value \\
\hline$\beta_{0}$ & INTERCPT & 0.4426 & 3.62 & $* * *$ & 0.4425 & 3.44 & $* * *$ & 0.4649 & 3.53 & $* * *$ \\
\hline
\end{tabular}




\section{Continued}

\begin{tabular}{|c|c|c|c|c|c|c|c|c|c|c|}
\hline$\beta_{1}$ & VOLPOST & -0.0264 & -2.45 & $* *$ & -0.0275 & -2.43 & $* *$ & -0.0294 & -2.54 & $* *$ \\
\hline$\beta_{2}$ & HIGHSPREAD & 0.0638 & 1.96 & * & 0.0827 & 2.42 & $* *$ & 0.0842 & 2.41 & $* *$ \\
\hline$\beta_{3}$ & $\begin{array}{c}\text { VOLPOST } \\
{ }^{*} H I G H S P R E A D\end{array}$ & -0.0949 & -2.56 & $* *$ & -0.1145 & -2.94 & $* * *$ & -0.1191 & -2.98 & $* * *$ \\
\hline$\beta_{4}$ & $B E T A$ & -0.0151 & -1.15 & & -0.0199 & -1.44 & & -0.0201 & -1.43 & \\
\hline$\beta_{5}$ & $S I Z E$ & -0.0125 & -2.84 & $* * *$ & -0.0112 & -2.43 & $* *$ & -0.0123 & -2.61 & $* *$ \\
\hline$\beta_{6}$ & $M T B$ & -0.0093 & -2.34 & $* *$ & -0.0104 & -2.50 & $* *$ & -0.0126 & -2.95 & $* * *$ \\
\hline$\beta_{7}$ & $R D E B T$ & 0.2242 & 5.83 & $* * *$ & 0.2171 & 5.38 & $* * *$ & 0.2316 & 5.60 & $* * *$ \\
\hline$\beta_{8}$ & $R O A$ & 0.0265 & 0.24 & & 0.0081 & 0.07 & & 0.0857 & 0.71 & \\
\hline$\beta_{9}$ & PLIST & -0.0084 & -1.26 & & -0.0108 & -1.54 & & -0.0102 & -1.42 & \\
\hline$\beta_{10}$ & $D I N D$ & \multicolumn{2}{|c|}{ Included } & & \multicolumn{3}{|c|}{ Included } & \multicolumn{3}{|c|}{ Included } \\
\hline & F & & 11.16 & $* * *$ & & 10.83 & $* * *$ & & 11.23 & $* * *$ \\
\hline & $\operatorname{Adj} . R^{2}$ & & $52 \%$ & & & $51 \%$ & & & $52 \%$ & \\
\hline & $\mathbf{N}$ & & 152 & & & 152 & & & 152 & \\
\hline
\end{tabular}

Note: See Appendix for variable definitions. ${ }^{* * *}$, ${ }^{* *}$, and ${ }^{*}$ represent significance at the $1 \%, 5 \%$, and $10 \%$ levels, respectively, in two-tailed tests.

After VFP, the FSS of Korea enforced mandatory adoption of XBRL on listed firms as of the 2007 accounting year. Hence, the effects of mandatory XBRL adoption on any incremental change in the cost of equity capital with voluntary XBRL filers is of significant interest to regulators and investors. To examine whether an incremental effect exists on the cost of capital for voluntary adopters after mandatory XBRL adoption, we form a 1:1 (1:2) matching sample for two years before (2005 and 2006) and two years after (2008 and 2009) the mandatory adoption. The sample consists of 108 (92) firm-years for voluntary adopters that adopted XBRL before 2007 and 108 (184) firm-years for mandatory adopters. Mandatory adopters are firms that first adopted the XBRL system in 2007.

Panel A of Table 1 shows the results of the regression analyses with 1:1 matching sample firms. All coefficients of MANDPOST are negative and significant at the 5 or 10 percent significance level $\left(\mathrm{t}=-1.96^{*}--3.11^{\star *}\right)$, suggesting that mandatory filers experience incremental reductions in the cost of equity capital after the formal adoption of XBRL. However, during the period, no significant difference exists in the cost of equity capital between voluntary and mandatory filers (VOLXBRL).

An interaction term (VOLXBRL $L^{\star}$ MANDPOST) is included in the model to examine whether any incremental effect of mandatory XBRL adoption existed for voluntary filers over mandatory filers. In Panel A of Table 1, the combined coefficients of MANDPOST and VOLXBRL MANDPOST $\left(\beta_{1}+\beta_{3}\right)$ are negative and significant at least at the 10 percent level $\left(-0.0222^{\star}--0.0264^{\star *}\right)$. These negative coefficients suggest that mandatory XBRL adoption is still effective in reducing the cost of equity capital for voluntary filers even though the VFP effect 
was already reflected in the year of voluntary adoption. The results of mandatory XBRL adoption with 1:2 matching samples are qualitatively the same in the directions and statistical significances of the coefficients (see Panel B of Table 1).

We would like to determine whether any learning effects exist after mandatory XBRL adoption. Despite the short time interval between voluntary and mandatory adoption of XBRL, the spontaneity and preparation of voluntary filers for XBRL adoption can work more positively with time. To examine the learning effects of XBRL adoption, we placed separate dummy variables for each of post-period (MANDPOST $T_{\mathrm{t}+1}$ for 2008 and $M A N D P O S T_{\mathrm{t}+2}$ for 2009). If any learning effects exist from XBRL adoption, then $M A N D P O S T_{\mathrm{t}+2}$ will show a larger negative and significant value than $M A N D P O S T_{\mathrm{t}+1}$. If the learning effects of voluntary filers are greater than those of mandatory filers, then the interactions of $\operatorname{VOLXBRL}^{\star} \mathrm{MANDPOST}_{\mathrm{t}+1}$ and $\mathrm{t}+2$ will be negative and significant.

Table 5 presents the results of the regression analyses using two separate dummy variables (MANDPOST $\mathrm{T}_{\mathrm{t}+1}$ and MANDPOST $_{\mathrm{t}+2}$ ) and interactions terms $\left(\right.$ VOLXBRL $^{\star}$ MANDPOST $_{t+1}$ and VOLXBRL $\left.{ }^{\star} \mathrm{MANDPOST}_{\mathrm{t}+2}\right)$. Mandatory filers experience sharper declines in cost than voluntary filers in the first year of mandatory XBRL adoption. However, the declines in the cost of equity capital do not last long, with no effects in the second year, whereas voluntary filers experienced not strong but continuous reductions in the cost. A comparison of the learning effects between the two groups shows that no incremental reductions in voluntary filers occurred in the first year. However, in the second year, voluntary filers show incremental reductions in the cost of equity capital, whereas the cost of equity capital of mandatory filers does not change. All of the binding coefficients $(\beta 1+\beta 4$ and $\beta 2+\beta 5)$ are negative and significant at the 10 percent level with respect to CEC_GM with 1:1 matching samples. The interaction terms of the second year $\left(\mathrm{VOLXBRL}^{\star} \mathrm{MANDPOST}_{\mathrm{t}+2}\right.$ ) show negative coefficients that are significant at the 10 percent level with respect to CEC_PEG with both matching samples (Panels A and B).

\subsection{Supplementary Analyses: Efficiency-Timely Disclosure, Cost of Equity Capital, and Learning Effects}

The primary purpose of adopting the XBRL system is to improve efficiency in information processing procedures by reducing the time and effort required for information production. This improved efficiency facilitates timely and more frequent disclosures and enables effective communication between investors and firms. Thus, XBRL is expected to improve the value relevance of financial reporting [63] [64]. The following empirical models test whether XBRL adoption makes firms provide more timely disclosures.

$$
\begin{aligned}
& \text { LAG_SIGN2FULL }(S I G N 2 A U D I T \text { or SIGN2AUDIT_CON })_{i t} \\
&=\alpha_{i t}+\beta_{1} \text { VOLPOST } \\
&+\beta_{5} \text { RDEBT }_{i t}+\beta_{6} \text { RCFOTENSITY }_{i t}+\beta_{3} \text { BIG }_{i t}+\beta_{4} \text { SIZE }_{i t}+\beta_{8} L O S S_{i t}+\beta_{9} \text { SIGN }_{i t} \\
&+\beta_{10} \text { MSH }_{i t}+\beta_{11} \text { FSH }_{i t}+\beta_{12} \text { HITECH }_{i t}+\varepsilon_{i t}
\end{aligned}
$$


Table 5. Effect on cost of capital for mandatory vs. voluntary XBRL adopters: two-period learning effect. (a) 1: 1 matching sample; (b) $1: 2$ matching sample.

(a)

\begin{tabular}{|c|c|c|c|c|c|c|c|c|c|c|}
\hline & \multirow[t]{2}{*}{ Dependent } & \multicolumn{3}{|c|}{$C E C \_P E G$} & \multicolumn{3}{|c|}{$C E C_{-} G M$} & \multicolumn{3}{|c|}{$C E C \_M P E G$} \\
\hline & & Coeff. & t-value & & Coeff. & t-value & & Coeff. & t-value & \\
\hline$\beta_{0}$ & INTERCPT & 0.9717 & 7.29 & $* * *$ & 0.9957 & 6.94 & $* * *$ & 0.9921 & 6.97 & $* * *$ \\
\hline$\beta_{1}$ & MANDPOST08 & -0.0744 & -4.80 & $* * *$ & -0.0793 & -4.76 & $* * *$ & -0.0895 & -5.41 & $* * *$ \\
\hline$\beta_{2}$ & MANDPOST09 & 0.0148 & 1.00 & & 0.0094 & 0.59 & & 0.0054 & 0.34 & \\
\hline$\beta_{3}$ & $V O L X B R L$ & -0.0021 & -0.15 & & -0.0038 & -0.26 & & -0.0094 & -0.65 & \\
\hline$\beta_{4}$ & $V O L X B R L^{\star} M A N D P O S T 08$ & 0.0467 & 2.29 & $* *$ & 0.0498 & 2.27 & $* *$ & 0.0580 & 2.66 & $* * *$ \\
\hline$\beta_{5}$ & VOLXBRL $L^{*}$ MANDPOST09 & -0.0346 & -1.68 & * & -0.0354 & -1.61 & & -0.0271 & -1.24 & \\
\hline$\beta_{6}$ & $B E T A$ & 0.0163 & 1.43 & & 0.0156 & 1.27 & & 0.0180 & 1.48 & \\
\hline$\beta_{7}$ & $S I Z E$ & -0.0337 & -7.40 & $* * *$ & -0.0336 & -6.84 & $* * *$ & -0.0333 & -6.85 & $* * *$ \\
\hline$\beta_{8}$ & $M T B$ & -0.0108 & -4.06 & $* * *$ & -0.0121 & -4.24 & $* * *$ & -0.0132 & -4.64 & $* * *$ \\
\hline$\beta_{9}$ & $R D E B T$ & 0.2752 & 7.96 & $* * *$ & 0.2825 & 7.60 & $* * *$ & 0.2816 & 7.63 & $* * *$ \\
\hline$\beta_{10}$ & $R O A$ & 0.1918 & 2.22 & $* *$ & 0.2070 & 2.23 & $* *$ & 0.2408 & 2.61 & $* * *$ \\
\hline$\beta_{11}$ & PLIST & 0.0118 & 1.74 & * & 0.0126 & 1.73 & * & 0.0123 & 1.70 & * \\
\hline \multirow[t]{6}{*}{$\beta_{12}$} & $D I N D$ & \multicolumn{3}{|c|}{ Included } & \multicolumn{3}{|c|}{ Included } & \multicolumn{3}{|c|}{ Included } \\
\hline & F-value & & 15.00 & $* * *$ & & 14.28 & $* * *$ & & 15.77 & $* * *$ \\
\hline & Adj. $R^{2}$ & & $56 \%$ & & & $54 \%$ & & & $57 \%$ & \\
\hline & $\mathbf{N}$ & & 216 & & & 216 & & & 216 & \\
\hline & $\beta_{1}+\beta_{4}$ & -0.0276 & 3.55 & * & -0.0295 & 3.48 & * & -0.0315 & 4.04 & $* *$ \\
\hline & $\beta_{2}+\beta_{5}$ & -0.0197 & 1.92 & & -0.0260 & 2.90 & * & -0.0217 & 2.04 & \\
\hline
\end{tabular}

(b)

\begin{tabular}{|c|c|c|c|c|c|c|c|c|c|c|}
\hline & \multirow{2}{*}{ Dependent } & \multicolumn{3}{|c|}{$C E C \_P E G$} & \multicolumn{3}{|c|}{$C E C \_G M$} & \multicolumn{3}{|c|}{$C E C \_M P E G$} \\
\hline & & Coeff. & $\mathrm{t}$-value & & Coeff. & $t$-value & & Coeff. & $\mathrm{t}$-value & \\
\hline$\beta_{0}$ & INTERCPT & 0.9715 & 8.82 & $* * *$ & 1.0263 & 8.65 & $* * *$ & 1.0485 & 8.70 & $* * *$ \\
\hline$\beta_{1}$ & MANDPOST08 & -0.0460 & -4.21 & $* * *$ & -0.0500 & -4.26 & $* * *$ & -0.0550 & -4.61 & $* * *$ \\
\hline$\beta_{2}$ & MANDPOSTO9 & 0.0154 & 1.50 & & 0.0101 & 0.91 & & 0.0088 & 0.78 & \\
\hline$\beta_{3}$ & $V O L X B R L$ & 0.0167 & 1.49 & & 0.0182 & 1.50 & & 0.0155 & 1.27 & \\
\hline$\beta_{4}$ & $V O L X B R L^{*} M A N D P O S T 08$ & 0.0132 & 0.75 & & 0.0163 & 0.86 & & 0.0194 & 1.00 & \\
\hline$\beta_{5}$ & VOLXBRL $L^{*} A N D P O S T 09$ & -0.0314 & -1.80 & * & -0.0310 & -1.65 & & -0.0250 & -1.31 & \\
\hline$\beta_{6}$ & $B E T A$ & 0.0265 & 3.12 & $* * *$ & 0.0256 & 2.79 & $* * *$ & 0.0249 & 2.67 & $* * *$ \\
\hline$\beta_{7}$ & $S I Z E$ & -0.0343 & -9.17 & $* * *$ & -0.0352 & -8.74 & $* * *$ & -0.0360 & -8.79 & $* * *$ \\
\hline$\beta_{8}$ & $M T B$ & -0.0110 & -4.88 & $* * *$ & -0.0129 & -5.29 & $* * *$ & -0.0141 & -5.69 & $* * *$ \\
\hline$\beta_{9}$ & $R D E B T$ & 0.2882 & 10.02 & $* * *$ & 0.3080 & 9.94 & $* * *$ & 0.3092 & 9.82 & $* * *$ \\
\hline$\beta_{10}$ & $R O A$ & 0.1447 & 1.77 & * & 0.1424 & 1.61 & & 0.1822 & 2.03 & $* *$ \\
\hline$\beta_{11}$ & PLIST & 0.0099 & 1.84 & * & 0.0094 & 1.63 & & 0.0090 & 1.54 & \\
\hline
\end{tabular}


Continued

\begin{tabular}{|c|c|c|c|c|c|c|c|c|c|c|c|}
\hline \multirow[t]{6}{*}{$\beta_{12}$} & & $D I N D$ & & Included & & & Included & & & Included & \\
\hline & & F & & 16.74 & $* * *$ & & 16.50 & $* * *$ & & 17.00 & $* * *$ \\
\hline & & Adj. $R^{2}$ & & $53 \%$ & & & $52 \%$ & & & $53 \%$ & \\
\hline & & $\mathrm{N}$ & & 276 & & & 276 & & & 276 & \\
\hline & $\beta_{1}+\beta_{4}$ & F-value & -0.0328 & 5.06 & $* *$ & -0.0338 & 4.63 & $* *$ & -0.0356 & 5.00 & $* *$ \\
\hline & $\beta_{2}+\beta_{5}$ & F-value & -0.0160 & 1.26 & & -0.0209 & 1.85 & & -0.0162 & 1.07 & \\
\hline
\end{tabular}

Note: See Appendix for variable definitions. ${ }^{* *}{ }^{* *}$, and ${ }^{*}$ represent significance at the $1 \%, 5 \%$, and $10 \%$ levels, respectively, in two-tailed tests.

$$
\begin{aligned}
& L A G \_S I G N 2 F U L L(S I G N 2 A U D I T \text { or SIGN2AUDIT_CON })_{i t} \\
& =\alpha_{i t}+\beta_{1} \text { MANDPOST0 }_{i t}+\beta_{2} \text { MANDPOST09 }{ }_{i t}+\beta_{3} \text { VOLXBRL }_{i t} \\
& +\beta_{4} \text { VOLXBRL } * \text { MANDPOST08 }{ }_{i t}+\beta_{5} \text { VOLXBRL } * \text { MANDPOST09 }{ }_{i t} \\
& +\beta_{6} \text { INTENSITY }_{i t}+\beta_{7} \text { BIG }_{i t}+\beta_{8} \text { SWITCH }_{i t}+\beta_{9} \text { RDEBT }_{i t} \\
& +\beta_{10} \text { RCFOTL }_{i t}+\beta_{11} \text { SIZE }_{i t}+\beta_{12} \text { LOSS }_{i t}+\beta_{13} \text { SIGN }_{i t} \\
& +\beta_{14} M_{S S H}+\beta_{15} F S H_{i t}+\beta_{16} H_{T T E C H}+\varepsilon_{i t}
\end{aligned}
$$

where,

LAG_SIGN2FULL: period between audit report date and the date the annual report is uploaded on the DART system;

$L A G \_S I G N 2 A U D I T$ : period between audit report date and the date the audit report is uploaded on the DART system;

LAG_SIGN2AUDIT_CON: period between consolidated-audit report date and the date the consolidated-audit report is uploaded on the DART system;

$\operatorname{VOLPOST}(M A N D P O S T): 1$ if the sample year is after voluntary (mandatory)

$\mathrm{XBRL}$ adoption, and 0 otherwise;

INTENSITY: accrual intensity, (NI-CFO)/SALES;

VOLXBRL: 1 if firms voluntarily adopted XBRL before the year of mandatory adoption, and 0 otherwise, in the years after mandatory adoption;

BIG4: 1 if an auditor is one among the BIG4 audit firms, and 0 otherwise;

$S W I T C H: 1$ if a firm switches its auditor, and 0 otherwise;

$R D E B T$ : total debt to total assets ratio;

RCFOTL: operating cash flows/total debt;

SIZE: natural logarithm of total assets;

LOSS: 1 if a firm experiences a loss, and 0 otherwise;

$S I G N$ : 1 if a firm experiences an increase in net income, and 0 otherwise;

$M S H$ : proportion of primary shareholder ownership;

FSH: proportion of foreign shareholder ownership; and

HITECH: 1 if a firm is in a high tech industry, and 0 otherwise.

The results (untabulaed) show significant negative associations between VOLPOST and three other factors: the period between the audit report date and the date a firm's annual report is uploaded onto the DART system ( $\left.L A G \_S I G N 2 F U L L\right)$, the period between the audit report date and the date a firm uploaded its audit report onto the DART system (LAG_SIGN2AUDIT), 
and the period between the audit report date of the consolidated financial statement and the date a firm uploaded its consolidated audit report onto the DART system (LAG_SIGN2AUDIT_CON) at least at the 5 percent level. This indicates that reporting lags are significantly reduced after voluntary XBRL adoption. The results show that reporting lags are reduced after mandatory filing and the reduction tended to be greater in 2009. After the mandatory filing, firms that have already adopted XBRL voluntarily experience additional reductions in reporting lags $\left(\beta_{1}+\beta_{4}\right.$ and $\left.\beta_{2}+\beta_{5}\right)$. Using natural logarithm of the number of days in reporting lags provides qualitatively the same results. In particular, the reduction of audit report lags for voluntary filers tends to be greater than that for mandatory filers with time after the adoption.

Müller-Wickop, N., Schultz, M., \& Nüttgens, M. [63] suggest that XBRL adoption improves the efficiency of information producers by shortening reporting lags and also improves the effectiveness of communication between producers and information users. The effect of the adoption on the cost of capital is, therefore, expected to be greater for those who experienced the reduction in reporting lags. Thus, this paper also examines the effect of cost of capital for voluntary XBRL adopters by report lag group. The results show that the adoption (VOLPOST) is negative and significant suggesting that the adoption reduces the cost of capital for those with shortened reporting lags (untabulated). However, with lengthened reporting lags, the adoption (VOLPOST) is insignificant. These results together imply that firms adopting XBRL experience benefits in terms of the savings of cost of capital only when they are able to reduce reporting lags. For those with shortened reporting lags, the effect of the first year of mandatory adoption (MANDPOST08) is negative and significant at the 1 percent level for all reporting lags. However, the effect of the second year of mandatory adoption (MANDPOST09) is generally insignificant except for those with unchanging or lengthening reporting lags only with regard to the date a firm's annual report is uploaded on the DART system (LAG_SIGN2FULL) (untabulated). In summary, the adoption of XBRL contributes to the improvement of information production efficiency in terms of reporting lags and also reduces the cost of capital. In particular, the effect of the adoption on the cost of capital tends to be greater for those with shortened reporting lags and also tends to be greater with time.

\section{Conclusions}

The voluntary adoption of XBRL-based financial disclosure systems has improved information users' accessibility, and therefore enables more timely and efficient decision-making for users. Improvements in the accessibility and availability of information reduce information asymmetry, which results in lowering the information risk recognized by users. Thus, we expect that XBRL adoption engenders a decline in a firm's cost of capital with respect to information risk. The XBRL system is an object-data-oriented system based on XML and defines 
standardized accounting information under the XBRL taxonomy. The system facilitates various reproductions of information and uses possible information that matches the purpose of information users through flexible search functions and extended compatibility.

This study investigates whether the voluntary adoption of an XBRL-based financial reporting system reduces the cost of equity capital. We also examine whether the reduction in the cost of equity capital depends on each firm's level of asymmetric information. Finally, we examine whether the 2007 mandatory adoption of the GAAP-based XBRL by Korean listed firms resulted in an incremental decrease in the cost of equity capital after operating the VFP of XBRL. This study further examines whether XBRL adoption improves the efficiency of information producers using reporting lags, and whether the reduction in reporting lags affects the cost of capital.

We find that the adoption of VFP significantly reduces the cost of equity capital. Furthermore, voluntary filers suffering from higher information asymmetry experience larger decreases in the cost of equity capital. These results are consistent with reduced information asymmetry from XBRL adoption because of standardized financial information and the progress of user-friendly disclosure systems through XBRL taxonomy. In addition, we find that the cost of equity capital decreased for firms that mandatorily adopted XBRL in 2007. This result suggests that both mandatory and voluntary adopters can benefit from a change in the technical information environment. Although no clear evidence exists of an incremental effect with voluntary filers after the mandatory adoption of XBRL, voluntary filers seem to experience "learning-by-doing" effects over time.

We find that the reporting lags are reduced for both voluntary filers and mandatory filers. This result suggests that XBRL adoption improves the efficiency of information producers. In particular, mandatory filers show incremental lag reduction with time. Also, we find that the greater the reduction of reporting lags, the higher the reduction of the cost of capital. In the case of audit report lag, voluntary filers experience a greater incremental reduction in the cost of capital as the lag shortens. This result suggests that those who voluntarily adopt XBRL prior to mandatory filing experience "learning-by-doing" effects over time.

This study provides evidence of the positive effect of an adoption of new information technology, not only for voluntary but also for mandatory adopters. This positive effect is applicable not only for information users but also information producers. Countries that plan to or are about to adopt a new information technology system in capital market can gain useful policy insights from the results of this study. Future studies can extend this work to determine whether the positive effects of a new information technology system are sustained after changes in accounting standards such as IFRS, the legal environment, and corporate governance. Determinants of the adoption of new information technology can also provide useful information over mechanisms related to business decision-making by managers. 


\section{Conflicts of Interest}

The authors declare no conflicts of interest regarding the publication of this paper.

\section{References}

[1] Kini, O. and Mian, S. (1995) Bid-Ask Spread and Ownership Structure. Journal of Financial Research, 18, 401-414. https://doi.org/10.1111/j.1475-6803.1995.tb00574.x

[2] Cheng, L., Firth, M., Leung, T. and Rui, O. (2006) The Effects of Insider Trading on Liquidity. Pacific-Basin Finance Journal, 14, 467-483.

https://doi.org/10.1016/j.pacfin.2006.01.006

[3] Kanagaretnam, K., Lobo, G. and Whalen, D. (2007) Does Good Corporate Governance Reduce Information Asymmetry around Quarterly Earnings Announcements? Journal of Accounting and Public Policy, 26, 497-522. https://doi.org/10.1016/j.jaccpubpol.2007.05.003

[4] Chung, K., Elder, J. and Kim, J. (2010) Corporate Governance and Liquidity. Journal of Financial and Quantitative Analysis, 45, 265-291. https://doi.org/10.1017/S0022109010000104

[5] Jaffe, J. (1974) Special Information and Insider Trading. Journal of Business, 47, 410-428. https://doi.org/10.1086/295655

[6] Shleifer, A. and Vishny, R. (1986) Large Shareholders and Corporate Control. Journal of Political Economy, 95, 461-488. https://doi.org/10.1086/261385

[7] Chiang, R. and Venkatesh, P. (1988) Insider Holdings and Perception of Information Asymmetry: A Note. Journal of Finance, 43, 1041-1048. https://doi.org/10.1111/j.1540-6261.1988.tb02622.x

[8] Seyhun, N. (1986) Insider Profits, Costs of Trading, and Market Efficiency. Journal of Financial Economics, 16, 189-212. https://doi.org/10.1016/0304-405X(86)90060-7

[9] Morck, R., Shleifer, A. and Vishny, R. (1988) Management Ownership and Market Valuation: An Empirical Analysis. Journal of Financial Economics, 20, 293-315. https://doi.org/10.1016/0304-405X(88)90048-7

[10] Glosten, L. and Milgrom, P. (1985) Bid, Ask, and Transaction Prices in a Specialist Market with Heterogeneously Informed Traders. Journal of Financial Economics, 14, 71-100. https://doi.org/10.1016/0304-405X(85)90044-3

[11] Lang, M. and Lundholm, R. (1996) Corporate Disclosure Policy and Analyst Behavior. The Accounting Review, 71, 467-492.

[12] Hope, O. (2003) Accounting Policy Disclosures and Analysts' Forecasts. Contemporary Accounting Research, 20, 295-321. https://doi.org/10.1506/LA87-D1NF-BF06-FW1B

[13] Easley, D. and O'Hara, M. (2004) Information and the Cost of Capital. Journal of Finance, 59, 1553-1583. https://doi.org/10.1111/j.1540-6261.2004.00672.x

[14] Christensen, P., Rosa, L. and Feltham, G. (2010) Information and the Cost of Capital: An Ex-Ante Perspective. The Accounting Review, 85, 817-848. https://doi.org/10.2308/accr.2010.85.3.817

[15] Bloomfield, R. and Fischer, P. (2011) Disagreement and the Cost of Capital. Journal of Accounting Research, 49, 41-68. https://doi.org/10.1111/j.1475-679X.2010.00389.x

[16] Stulz, R. (1990) Managerial Discretion and Optimal Financing Policies. Journal of Financial Economics, 26, 3-27. https://doi.org/10.1016/0304-405X(90)90011-N

[17] May, D. (1995) Do Managerial Motives Influence Firm Risk-Reduction Strategies? 
Journal of Finance, 50, 1291-1308.

[18] Fluck, Z. (1998) Optimal Financial Contracting: Debt versus Outside Equity. Review of Financial Studies, 11, 383-418. https://doi.org/10.1093/rfs/11.2.383

[19] Myers, S. (2000) Outside Equity. Journal of Finance, 55, 1005-1037. https://doi.org/10.1111/0022-1082.00239

[20] Pawlina, G. and Renneboog, L. (2005) Is Investment-Cash Flow Sensitivity Caused by the Agency Cost or Asymmetric Information? Evidence from the UK. European Financial Management, 11, 483-513. https://doi.org/10.1111/j.1354-7798.2005.00294.x

[21] Weber, R. (2003) XML, XBRL, and the Future of Business and Business Reporting. In: Roohani, S.T., Eds., Trust and Data Assurance in Capital Markets. The Role of Technology Solutions, Smithfield, Rhode Island.

[22] Hodge, F., Kennedy, J. and Maines, L. (2004) Does Search-Facilitating Technology Improve the Transparency of Financial Reporting? The Accounting Review, 79, 687-703.

[23] Cox, C. (2006) The Interactive Data Revolution: Improved Disclosure for Investors, Less Expensive Reporting for Companies. http://www.sec.gov/news/speech/2006/spch053006cc.htm

[24] Roohani, S., Furusho, Y. and Koizumi, M. (2009) XBRL: Improving Transparency and Monitoring Functions of Corporate Governance. International Journal of Disclosure and Governance, 6, 355-369. https://doi.org/10.1057/jdg.2009.17

[25] Yoon, H., Zo, H. and Ciganek, A. (2011) Does XBRL Adoption Reduce Information Asymmetry? Journal of Business Research, 64, 157-163.

[26] Diamond, D. (1985) Optimal Release of Information by Firms. Journal of Finance, 40, 1071-1094. https://doi.org/10.1111/j.1540-6261.1985.tb02364.x

[27] Chen, S., Harris, L., Li, W. and Wu, D. (2015) How Does XBRL Affect the Cost of Equity Capital? Evidence from an Emerging Market. Journal of International Accounting Research, 14, 123-145. https://doi.org/10.2308/jiar-51211

[28] Li, O., Ni, C. and Lin, Y. (2012) Does XBRL Adoption Reduce the Cost of Equity Capital? Working Paper, National University of Singapore, Singapore. http://papers.ssrn.com/sol3/papers.cfm?abstract_id=2131001

[29] Leuz, C. and Verrecchia, R. (2000) The Economic Consequences of Increased Disclosure. Journal of Accounting Research, 38, 91-124. https://doi.org/10.2307/2672910

[30] Diamond, D. and Verrecchia, R. (1991) Disclosure, Liquidity, and the Cost of Capital. Journal of Finance, 46, 1325-1360. https://doi.org/10.1111/j.1540-6261.1991.tb04620.x

[31] Clarkson, P., Guedes, J. and Thompson, R. (1996) On the Diversification, Observability, and Measurement of Estimation Risk. Journal of Financial and Quantitative Analysis, 31, 69-84. https://doi.org/10.2307/2331387

[32] Gode, D. and Mohanram, P. (2003) Inferring the Cost of Capital Using the Ohlson-Juettener Model. Review of Accounting Studies, 8, 399-431. https://doi.org/10.1023/A:1027378728141

[33] Francis, J., LaFond, R., Olsson, P. and Schipper, K. (2004) Costs of Equity and Earnings Attributes. The Accounting Review, 79, 967-1010. https://doi.org/10.2308/accr.2004.79.4.967

[34] Habib, A. (2006) Information Risk and the Cost of Capital: Review of the Empirical Literature. Journal of Accounting Literature, 25, 127-168. 
[35] He, W., Lepone, A. and Leung, H. (2013) Information Asymmetry and the Cost of Equity Capital. International Review of Economics \& Finance, 27, 611-620. https://doi.org/10.1016/j.iref.2013.03.001

[36] Healy, P. and Palepu, K. (2001) Information Asymmetry, Corporate Disclosure, and the Capital Markets: A Review of the Empirical Disclosure Literature. Journal of Accounting and Economics, 31, 405-440. https://doi.org/10.1016/S0165-4101(01)00018-0

[37] Myers, S. and Majluf, N. (1984) Corporate Financing and Investment Decisions When Firms Have Information that Investors Do Not Have. Journal of Financial Economics, 13, 187-222. https://doi.org/10.1016/0304-405X(84)90023-0

[38] Pinsker, R. and Li, S. (2008) Costs and Benefits of XBRL Adoption: Early Evidence. Communication of the ACM, 51, 47-51. https://doi.org/10.1145/1325555.1325565

[39] U.S. Securities and Exchange Commission (SEC) (2009) Interactive Data to Improve Financial Reporting. http://www.sec.gov/rules/final/2009/33-9002.pdf

[40] Blankespoor, E., Miller, B. and White, H. (2012) Initial Evidence on the Market Impact of the XBRL Mandate. Working Paper, School of Business, Stanford University.

[41] Premuroso, R. and Bhattacharya, S. (2008) Do Early and Voluntary Filers of Financial Information in XBRL Format Signal Superior Corporate Governance and Operating Performance? International Journal of Accounting Information Systems, $\mathbf{9}$, $1-20$.

[42] Kim, J. and Shi, H. (2012) Voluntary IFRS Adoption, Analyst Coverage and Information Quality: International Evidence. Journal of International Accounting Research, 11, 45-76. https://doi.org/10.2308/jiar-10216

[43] Botosan, C. (1997) Disclosure Level and the Cost of Equity Capital. The Accounting Review, 72, 323-349.

[44] Francis, J., Nanda, D. and Olsson, P. (2008) Voluntary Disclosure, Earnings Quality, and Cost of Capital. Journal of Accounting Research, 46, 1-47. https://doi.org/10.1111/j.1475-679X.2008.00267.x

[45] Lundholm, R. and Myers, L. (2002) Bringing the Future Forward: The Effect of Disclosure on the Returns-Earnings Relation. Journal of Accounting Research, 40, 809-839. https://doi.org/10.1111/1475-679X.00072

[46] Wang, M. and Hussainey, K. (2013) Voluntary Forward-Looking Statements Driven by Corporate Governance and Their Value Relevance. Journal Accounting and Public Policy, 32, 26-49. https://doi.org/10.1016/j.jaccpubpol.2013.02.009

[47] Daske, H., Hail, L. and Leuz, C. and Verdi, R. (2008) Mandatory IFRS Reporting around the World: Early Evidence on the Economic Consequences. Journal of Accounting Research, 46, 1085-1142.

[48] Easton, P. (2004) PE Ratios, PEG Ratios and Estimating the Implied Expected Rate of Return on Equity Capital. The Accounting Review, 79, 73-95. https://doi.org/10.2308/accr.2004.79.1.73

[49] Ohlson, J. and Juettner-Nautoth, B. (2005) Expected EPS and EPS Growth as Determinants of Value. Review of Accounting Studies, 10, 349-365. https://doi.org/10.1007/s11142-005-1535-3

[50] Sharpe, W. (1964) Capital Asset Prices: A Theory of Market Equilibrium under Conditions of Risk. Journal of Finance, 19, 425-442.

[51] Mossin, J. (1966) Equilibrium in a Capital Asset Market. Econometrica, 34, 768-783. https://doi.org/10.2307/1910098 
[52] Cha, S., Chung, J. and Yoo, Y. (2010) Corporate International Diversification and Cost of Equity Capital: Korean Evidence. Korean Management Review, 39, 157-175.

[53] Fama, E. and French, K. (1992) The Cross-Section of Expected Stock Return. Journal of Finance, 47, 427-465. https://doi.org/10.1111/j.1540-6261.1992.tb04398.x

[54] Khurana, I. and Raman, K. (2004) Litigation Risk and the Financial Reporting Credibility of Big Four vs. Non-Big Four Audits: Evidence from Anglo-American Countries. The Accounting Review, 79, 473-496.

[55] Muscarella, C. and Vetsuypens, M. (1989) The Underpricing of Second Initial Public Offerings. Journal of Financial Research, 12, 183-192. https://doi.org/10.1111/j.1475-6803.1989.tb00512.x

[56] Coller, M. and Yohn, T. (1997) Management Forecasts and Information Asymmetry: An Examination of Bid-Ask Spreads. Journal of Accounting Research, 35, 181-191. https://doi.org/10.2307/2491359

[57] Fu, R., Kraft, A. and Zhang, H. (2012) Financial Reporting Frequency, Information Asymmetry, and the Cost of Equity. Journal of Accounting and Economics, 54, 132-149. https://doi.org/10.1016/j.jacceco.2012.07.003

[58] Cho, S., Lee, C. and Pfeiffer Jr., R. (2013) Corporate Social Responsibility Performance and Information Asymmetry. Journal of Accounting and Public Policy, 32, 71-83. https://doi.org/10.1016/j.jaccpubpol.2012.10.005

[59] Zmijewski, M. (1984) Methodological Issues Related to the Estimation of Financial Distress Prediction Models. Journal of Accounting Research, 22, 59-82. https://doi.org/10.2307/2490859

[60] Diamond, D. (1989) Reputation Acquisition in Debt Markets. Journal of Political Economy, 97, 825-862. https://doi.org/10.1086/261630

[61] Pittman, J. and Fortin, S. (2004) The Impact of Auditor's Reputation on the Cost of Financing. Journal of Accounting and Economics, 37, 113-136. https://doi.org/10.1016/j.jacceco.2003.06.005

[62] Gul, F., Zhou, G. and Zhu, X. (2013) Investor Protection, Firm Informational Problems, Big-N Auditors, and Cost of Debt around the World. Auditing. A Journal of Practice \& Theory, 32, 1-30. https://doi.org/10.2308/ajpt-50462

[63] Müller-Wickop, N., Schultz, M. and Nüttgens, M. (2012) XBRL: Impacts, Issues and Future Research Directions. Enterprise Applications and Services in the Finance Industry, 135, 112-130.

[64] Efendi, J., Park, J.D. and Subramaniam, C. (2016) Does the XBRL Reporting Format Provide Incremental Information Value? A Study Using XBRL Disclosures during the Voluntary Filing Program. ABACUS, 52, 259-285.

https://doi.org/10.1111/abac.12079 


\section{Appendix: Variable Definitions}

CEC_PEG (GM/MPEG): a proxy for firms' cost of equity capital suggested in [32] and [48];

BETA: estimated beta ( $\beta$ ) from the CAPM;

SIZE: natural logarithm of the firm's equity market capitalization at the end of the lagged year;

$M T B$ : total market value $\mathrm{t}_{\mathrm{t}-1}$ scaled by the book value of total equity capital $\mathrm{t}_{\mathrm{t}-1}$;

$R D E B T$ : debt ratio; $R O A$ : net income scaled by total assets;

$R O A$ : net income scaled by total assets;

PLIST: natural logarithm of the number of years after a firm was listed in the markets.

VOLPOST: 1 if the sample year is in the post-XBRL period of voluntary adoption, and 0 otherwise;

HIGHSPREAD: if the natural logarithm of the bid-ask spread of a firm is greater than the median, then HIGHSPREAD $=1$, and HIGHSPREAD $=0$ otherwise;

SPREAD: (ask price-bid price) $/\{$ (ask price+bid price) $/ 2\}$ at the close of trade on each date;

MANDPOST: 1 if the sample year is after mandatory XBRL adoption, and 0 otherwise;

VOLXBRL: 1 if firms voluntarily adopted XBRL before the year of mandatory adoption, and 0 otherwise;

MANMANDPOST08/09: 1 if the sample year is after mandatory XBRL adoption in 2008 (MANDPOST08) or 2009 (MANDPOST09), and 0 otherwise;

$D I N D$ : dummy variables to control the effects of industries. 